\title{
Genetic diversity of NS5A protein from hepatitis $C$ virus genotype $3 a$ and its relationship to therapy response
}

\author{
Cíntia Bittar ${ }^{1}$, Ana Carolina G Jardim¹, Lilian HT Yamasaki ${ }^{1}$, Artur TL de Queiróz², Claudia MA Carareto', \\ João Renato R Pinho ${ }^{3,4}$, Isabel Maria VG de Carvalho-Mello ${ }^{5^{*}}$, Paula Rahal ${ }^{1}$
}

\begin{abstract}
Background: The quasispecies nature of HCV may have important implications for viral persistence, pathogenicity and resistance to antiviral agents. The variability of one of the viral proteins, NS5A, is believed to be related to the response to IFN therapy, the standard treatment for infection. In this study we analyzed the quasispecies composition of NS5A protein in patients infected with HCV genotype 3a, before IFN therapy.

Methods: Viral RNA was isolated from samples of 12 patients: four sustained virological responders (SVR), four nonresponders (NR), and four end-of-treatment responders (ETR). CDNA was synthesized, the NS5A region was amplified and the fragments obtained were cloned. Fifteen clones from each patient were sequenced with eight primers, generating 179 contigs.

Results: Higher values for substitution (either synonymous or non-synonymous) and for distance were found in the SVR group. However, the NR group showed relatively more non-synonymous mutations than the other groups, owing to the higher values of dN/dS in complete NS5A and most specific regions. Overall, NS5A protein is undergoing purifying selection, since all $\mathrm{dN} / \mathrm{dS}$ ratios values are below 0.5 .

Conclusions: Our study provides an overview of the genetic variability of complete NS5A protein in HCV genotype 3a.
\end{abstract}

\section{Background}

The hepatitis $\mathrm{C}$ virus $(\mathrm{HCV})$ is among the most successful of all persistent human viruses [1]. It is estimated that the global prevalence of $\mathrm{HCV}$ infection is $2.2 \%$, corresponding to about 130 million $\mathrm{HCV}$-positive persons worldwide [2]. The HCV genome consists of a singlestrand positive-sense RNA of approximately $9.6 \mathrm{~Kb}$ that contains an open reading frame coding for a polyprotein precursor of approximately 3000 residues. This precursor is cleaved by viral and host proteinases into the viral proteins: the structural protein core, E1, E2 and p7, and the nonstructural proteins NS2, NS3, NS4A, NS4B, NS5A and NS5B [3].

To date, six main HCV genotypes have been identified, which differ by about $30 \%$ in their nucleotide and

\footnotetext{
* Correspondence: imvgcmello@butantan.gov.br

${ }^{5}$ Butantan Institute, Viral Immunology Laboratory, Av Vital Brasil nº 1500, CEP 05503-900, Butantã, São Paulo, SP, Brazil
}

amino acid sequences [4]. Genotypes 1,2 and 3 and their subtypes have a global distribution; genotype 4 is found in Africa, genotype 5 in South Africa, and genotype 6 mainly in Asia [5]. In Brazil, Campiotto et al. (2005) reported the presence of genotypes 1, 2, 3, 4 and 5 [6].

The RNA-dependent RNA polymerase encoded by the NS5B gene is error-prone and lacks proofreading. As a result, base changes are introduced randomly into the viral genome [7]. Therefore, HCV replication is associated with a high mutation rate, giving rise to a mixed and changing population of mutants known as quasispecies $[4,8]$. The quasispecies nature of $\mathrm{HCV}$ may have important implications for viral persistence, pathogenicity and resistance to antiviral agents [8-11]. This is most problematic for the infected patient, because quasispecies variation confers remarkable adaptive potential on $\mathrm{HCV}$ and has been implicated in the evasion and 
control of the host response to infection and in differential sensitivity to IFN therapy. The hostile antiviral host environment may drive the proliferation of $\mathrm{HCV}$ "evasion variants" from a pre-existing quasispecies pool or through viral genetic adaptation [11]. However, intragenotype analysis of this diversity in the viral genome shows different degrees of variation; regions such as the 5'UTR and the core are highly conserved, the non-structural regions $2,3,5 \mathrm{~b}$ and the 3 'UTR are relatively variable, while the envelope regions E1 and E2 and the NS4 and the NS5A genes exhibit the highest sequence diversity [12]. Sequence analysis of the HCV NS5A coding region has similarly identified specific domains that exhibit sequence variation associated with the outcome of IFN therapy [13].

NS5A is the nonstructural HCV protein most frequently reported to be implicated in interferon resistance. It is a pleiotropic protein, involved both in viral replication and in many interactions with cellular signaling pathways, including the interferon anti-viral pathway [12]. This study analyzed the NS5A quasispecies pattern in patients infected with $\mathrm{HCV}$ genotype 3 before IFN plus ribavirin therapy, with the aim of elucidating its molecular constitution and relationship to treatment response.

\section{Results}

Viral load

The viral load data show that all patients presented high viral loads, as expected for pre-treatment samples, ranging from $\log 5.76$ to $\log 7.03$. There was no correlation between viral load and treatment response (Table 1).

\section{Sequencing}

This study generated 15 contig sequences of the full NS5A region from 11 patients; 14 sequences from patient RF80 could be sequenced, totaling 179 contigs.

\section{Quasispecies analysis}

Quasispecies analysis revealed that the HCV NS5A region was highly variable, as only three patients showed two identical nucleotide sequences (Figure 1A). The amino acid data showed more identical sequences owing to synonymous substitution, as can be seen when the nucleotide and amino acid patterns of patient RF15 are compared. All nucleotide sequences from this patient were different; however, the amino acid sequences showed one of the highest degrees of conservation (Figure 1B).

\section{Substitutions}

Nucleotide substitution analysis showed that the sustained virological response (SVR) group had the highest means of nucleotide and amino acid substitutions, except for the amino acid sequences of regions NLS and $\mathrm{V} 3$, where the end-of-treatment response (ETR) group showed the highest values (Table 2). However, none of the differences between groups were statistically significant.

To identify the mutation sites in the sequences used in this study, they were represented graphically according to the reference sequence NZL1 (GeneBank D17763) (Figure 2). This representation indicates that no specific mutation could be associated with any kind of treatment response. Figure 2 also shows that some of the nucleotide mutations resulted in stop codons. Of the nine stop codons found in the 179 sequences generated in this study, the site was the same in two or more clones in seven cases. The same stop codon sites were found in NS5A amino acids 4 (RF31 and RF145), 166 (RF60 - 2 clones and RF145) and 447 (RF07 and RF109). Also, the sites where the translation stop codon was observed showed no other mutation, except for one clone from patient RF145, which showed a mutation in aa 447 .

Table 1 Viral load.

\begin{tabular}{|c|c|c|c|c|c|}
\hline Patient & Therapy response & Viral load (UI/ml) & $\log$ & Mean & SEM* \\
\hline RF 015 & Sustained virological responder & 693.411 & 5,84 & 5.578 .634 & $+/-2.062 .880$ \\
\hline RF 018 & Sustained virological responder & 10.717 .120 & 7,03 & & \\
\hline RF 059 & Sustained virological responder & 6.070 .135 & 6,78 & & \\
\hline RF 080 & Sustained virological responder & 4.833 .870 & 6,68 & & \\
\hline RF 007 & Non responder & 569.141 & 5,76 & 2.348 .652 & $+/-703.684$ \\
\hline RF 060 & Non responder & 3.168 .112 & 6,50 & & \\
\hline RF 075 & Non responder & 3.735 .050 & 6,57 & & \\
\hline RF 145 & Non responder & 1.922 .304 & 6,28 & & \\
\hline RF 020 & End of treatment responder & 4.205 .798 & 6,62 & 2.422 .973 & $+/-688.016$ \\
\hline RF 031 & End of treatment responder & 919.193 & 5,96 & & \\
\hline RF 109 & End of treatment responder & 2.600 .972 & 6,42 & & \\
\hline RF 119 & End of treatment responder & 1.965 .928 & 6,29 & & \\
\hline
\end{tabular}

*SEM: standard error of the mean 


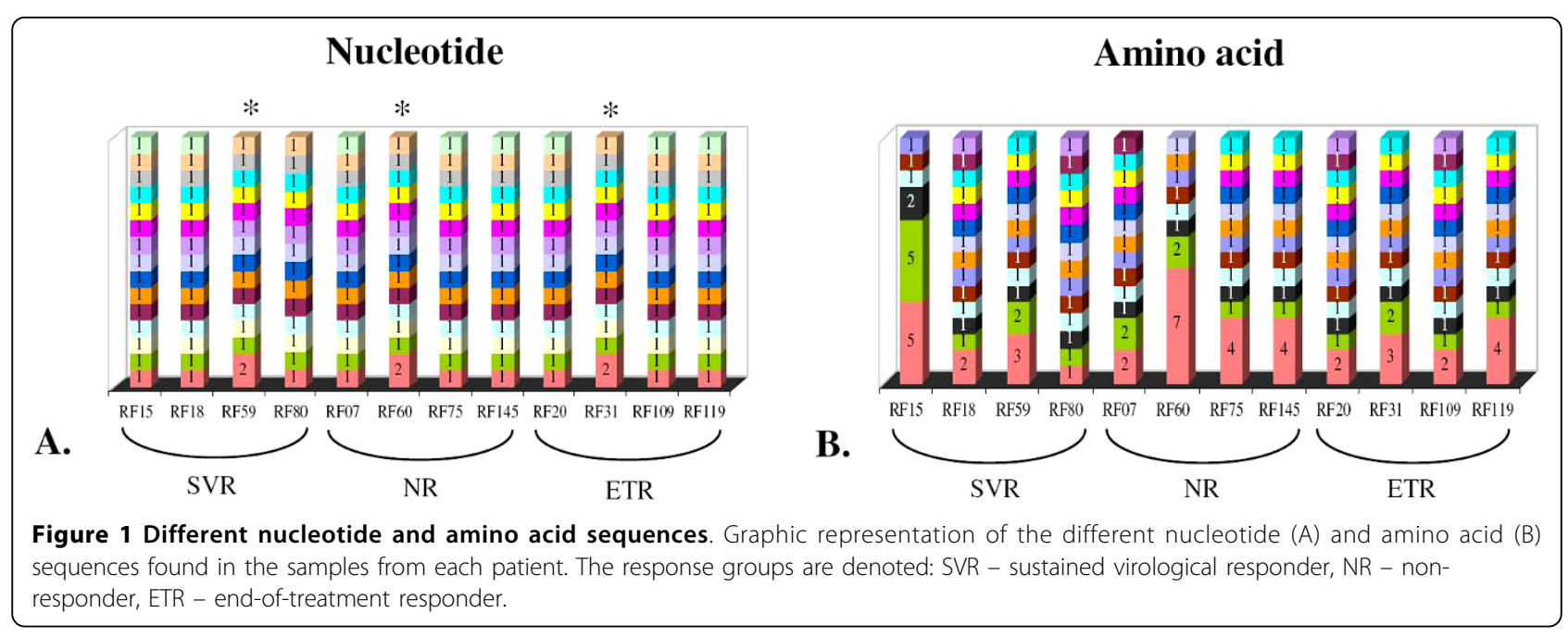

Table 2 Number of mutations, genetic distance, dN, dS and dN/dS.

\begin{tabular}{|c|c|c|c|c|c|c|c|c|c|c|}
\hline $\begin{array}{l}\text { Regions and types of } \\
\text { treatment response }\end{array}$ & $\begin{array}{c}\text { nt } \\
\text { mutations }\end{array}$ & $\begin{array}{c}\text { aa } \\
\text { mutations }\end{array}$ & $\begin{array}{c}\text { Genetic } \\
\text { distance } \\
\text { ws }\end{array}$ & $\begin{array}{c}\text { Genetic } \\
\text { distance } \\
\text { bs }\end{array}$ & dS ws & dS bs & $\begin{array}{l}\mathrm{dN} \\
\text { ws }\end{array}$ & $\mathrm{dN} b s$ & $\mathrm{dN} / \mathrm{dS}$ ws & $d N / d S$ bs \\
\hline \multicolumn{11}{|l|}{ NS5A } \\
\hline SVR & 29.85 & 7.03 & 0.022 & 0.064 & 0.0739 & $0.2519^{*}$ & 0.0075 & $0.0182^{*}$ & 0.0876 & $0.0672^{*}$ \\
\hline$N R$ & 13.41 & 4.65 & 0.01 & 0.053 & 0.0272 & $0.2075^{*}$ & 0.0054 & $0.0155^{*}$ & 0.1365 & $0.0761^{*}$ \\
\hline ETR & 26.21 & 5.77 & 0.0193 & 0.056 & 0.0506 & $0.2128^{*}$ & 0.0061 & $0.0164^{*}$ & 0.0759 & $0.0734^{*}$ \\
\hline \multicolumn{11}{|l|}{ CRS } \\
\hline SVR & 1.65 & 0.44 & 0.0203 & 0.055 & 0.1451 & $0.3114^{*} \mathrm{~b}$ & 0.0192 & $0.0412^{*}$ & $0.1382^{* a}$ & $0.1181^{*}$ \\
\hline$N R$ & 0.75 & 0.20 & 0.0093 & 0.044 & 0.0769 & $0.2303^{* c}$ & 0.0239 & $0.0203^{*}$ & $0.2917^{* a}$ & $0.0796^{*}$ \\
\hline ETR & 1.25 & 0.26 & 0.0155 & 0.037 & 0.119 & $0.1797^{*} b, * c$ & 0.0233 & $0.0223^{*}$ & 0.1596 & $0.1010^{*}$ \\
\hline \multicolumn{11}{|l|}{ PKR-bd } \\
\hline SVR & 5.21 & 1.23 & 0.0263 & 0.062 & 0.1308 & $0.2955^{*}$ & 0.0156 & $0.0171^{*}$ & 0.1028 & $0.0376^{*} \mathrm{~b}$ \\
\hline$N R$ & 2.08 & 0.85 & 0.0105 & 0.055 & 0.042 & $0.2857^{*}$ & 0.0156 & $0.0147^{*}$ & 0.4569 & $0.0390^{* c}$ \\
\hline ETR & 3.55 & 0.73 & 0.0178 & 0.048 & 0.092 & $0.2482^{*}$ & 0.0089 & $0.0098^{*}$ & 0.1343 & $0.0336 * b, * c$ \\
\hline \multicolumn{11}{|l|}{ ISDR } \\
\hline SVR & 3.04 & 0.60 & 0.0253 & 0.061 & 0.1696 & $0.3096^{*}$ & 0.0269 & $0.0219^{*}$ & 0.151 & $0.0472^{*}$ \\
\hline$N R$ & 1.17 & 0.40 & 0.0098 & 0.051 & 0.0537 & $0.2766^{*}$ & 0.022 & $0.0174^{*}$ & 0.4457 & $0.0521^{*}$ \\
\hline ETR & 2.01 & 0.13 & 0.0168 & 0.051 & 0.1335 & $0.2814^{*}$ & 0.0109 & $0.0111^{*}$ & 0.1485 & $0.0390^{*}$ \\
\hline \multicolumn{11}{|l|}{ NLS } \\
\hline SVR & 0.58 & 0.10 & 0.0213 & 0.099 & 0.2658 & $0.4935^{*}$ & 0.0617 & $0.0598^{* a}$ & 0.4523 & $0.1143^{*}$ \\
\hline NR & 0.20 & 0.03 & 0.0075 & 0.068 & 0.1399 & $0.2529^{*}$ & 0.0541 & $0.0555^{* a}$ & 0.3864 & $0.2166^{*}$ \\
\hline ETR & 0.47 & 0.16 & 0.0173 & 0.063 & 0.2367 & $0.2102^{*}$ & 0.0557 & 0.0607 & 0.2663 & $0.2705^{*}$ \\
\hline \multicolumn{11}{|l|}{ V3 } \\
\hline SVR & 1.69 & 0.76 & 0.0258 & 0.081 & 0.1088 & $0.2344^{*}$ & 0.0406 & $0.0622^{* a}$ & 0.3415 & $0.1940^{* a}$ \\
\hline$N R$ & 0.91 & 0.55 & 0.0138 & 0.063 & 0.0594 & $0.1246^{*}$ & 0.0313 & $0.0664^{*} a_{r} * c$ & 0.4752 & $0.4130 * a_{1} * c$ \\
\hline ETR & 1.37 & 0.83 & 0.0208 & 0.066 & 0.0868 & $0.1817^{*}$ & 0.0342 & $0.0488^{* c}$ & 0.4022 & $0.1996^{* c}$ \\
\hline
\end{tabular}

Values for number of mutations and for genetic distance, rates of synonymous substitution per synonymous site (dS), non-synonymous substitution per nonsynonymous site $(\mathrm{dN})$ and $\mathrm{dN} / \mathrm{dS}$ ratio obtained by ws and bs analysis for each response group regarding the complete NS5A and the regions studied.

* Significant difference among all groups; $\mathrm{p}<0.05$

* a Significant difference between SVR and NR; $p<0.05$

*b Significant difference between SVR and ETR; $p<0.05$

* c Significant difference between NR and ETR; $p<0.05$ 


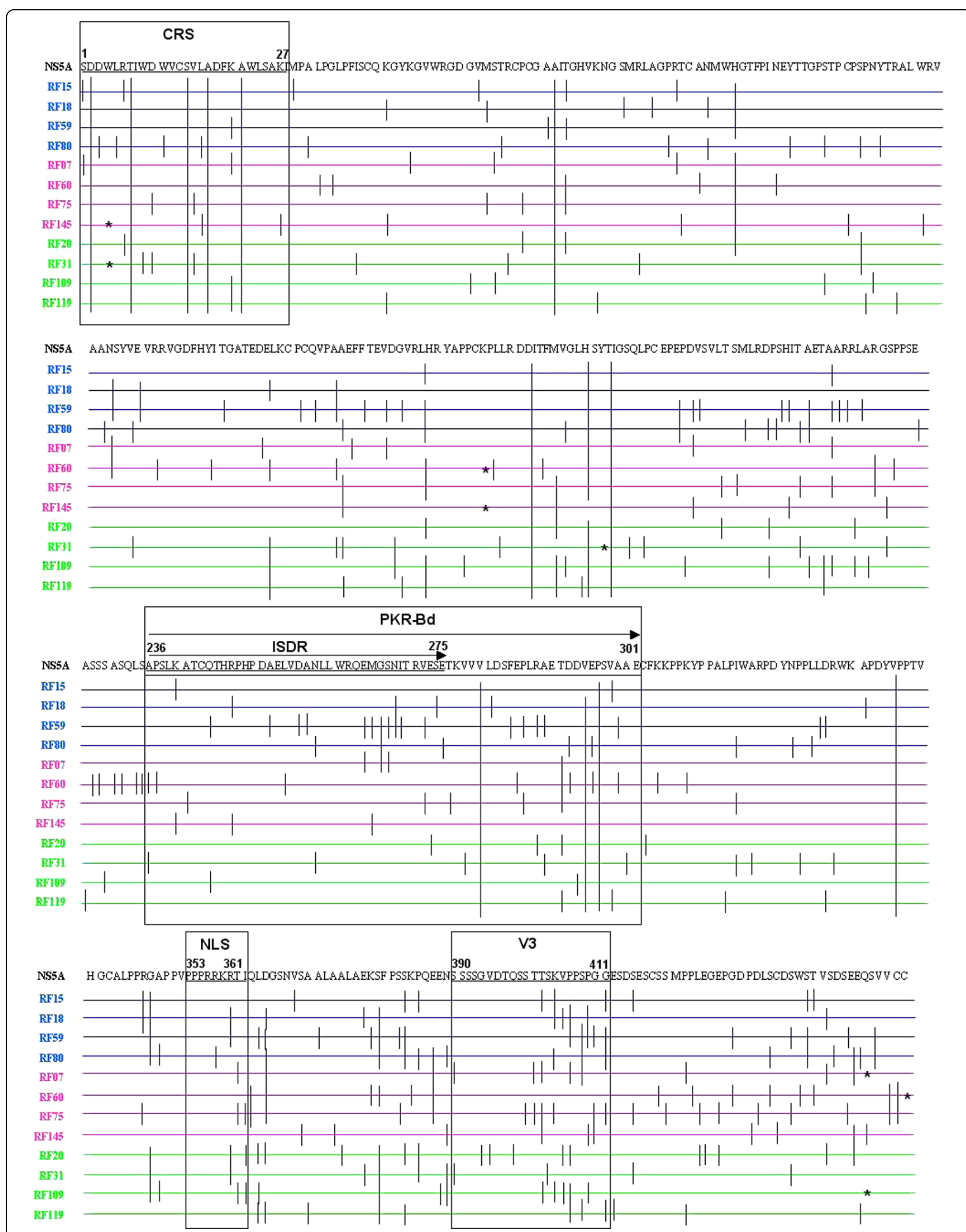

Figure 2 Mutation sites. Graphic representation of the mutation sites found in each patient, according to the reference sequence for genotype 3, NZL1 (GeneBank D17763). SVR patients are represented in blue, NR patients in pink, and ETR patients in green. 


\section{Substitution rates}

For the within-sample (ws) data, the mean rate of synonymous substitution per synonymous site (dS) was higher in the SVR group (Table 2). The rate of nonsynonymous substitution per non-synonymous site $(\mathrm{dN})$ was also higher in the SVR group, except for regions CRS and PKR-Bd. These data showed no statistically significant differences.

Between-sample (bs) analysis also showed a higher dS mean in the SVR group. SVR had the highest mean $d N$ values, except for regions NLS and V3. All the $b s$ data showed statistical significance, except for the dS means in CRS between SVR and ETR and between NR and ETR.

In the ws analysis, the $\mathrm{dN} / \mathrm{dS}$ ratio was higher in the NR group, except for the NLS region, where SVR had the highest ratio. In this analysis, only the difference between SVR and NR in the CRS region was statistically significant.

The $b s$ data showed higher $\mathrm{dN} / \mathrm{dS}$ ratios in NR for most of NS5A; regions CRS and NLS showed higher values in SVR and ETR, respectively. Statistical significance was observed in all regions, except for PKR-Bd between SVR and NR and for region V3 between SVR and ETR.

\section{Genetic distances}

The mean genetic distances for the complete NS5A region and the other regions studied were higher in the SVR group in either $w s$ or $b s$ analysis (Table 2). No statistically significant difference was found for genetic distance.

\section{Phylogenetic analysis}

Phylogenetic analysis was carried out using the 179 1356-bp sequences generated in this study, the reference sequence for genotype 3, NZL1 (GenBank accession number D17763), the six full-length NS5A sequences from genotype $3 \mathrm{a}$, with country information, available in GenBank (Accession numbers: AY956467; DQ430819; DQ430820; DQ437509; X76918; GQ300882.1), and 20 Brazilian NS5A sequences of 1308 bp (Accession numbers: EF207999.1 to EF208018.1). The resulting phylogenetic tree is presented in Figure 3. All sequences from clones from the same patient are grouped in a monophyletic branch, with high bootstrap values (95-100\%). There was no clustering in a monophyletic branch of the sequences from patients in the same treatment response group.

\section{Discussion}

RNA viruses have high mutation rates owing to lack of proofreading of the RNA polymerase. On the one hand, these high mutation rates can be deleterious for the

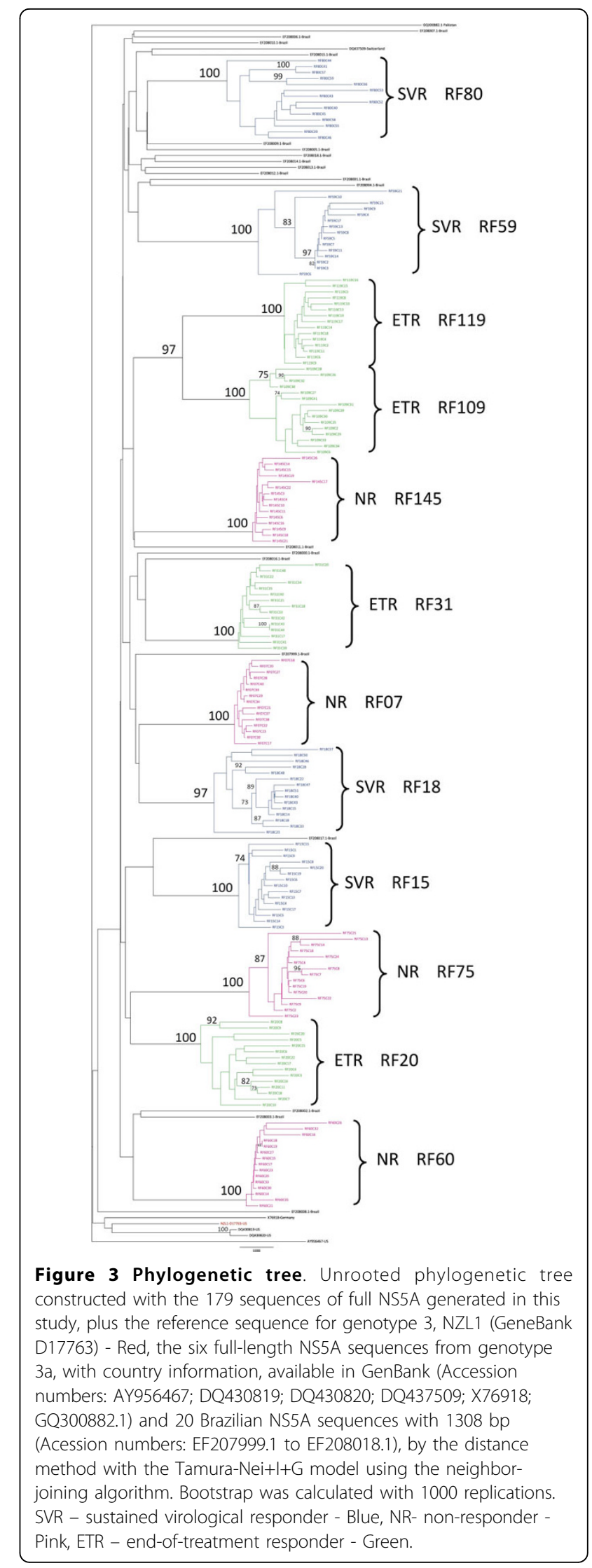


virus by creating non-viable strains; on the other, when the viral population is considered, they can also create a pool of potentially good mutations. The capacity of $\mathrm{HCV}$ to circulate as a pool of different but closely related strains, commonly called quasispecies, allows it to evolve and adapt to new environments and to overcome the challenges of infection $[4,8,14-16]$. The phylogenetic tree constructed in this work illustrates this characteristic and shows, for each patient, very similar but not identical strains with a monophyletic origin.

Our investigation of the genetic variability of the NS5A region from $\mathrm{HCV}$ 3a demonstrated the high variability of strains found in the same patient. The highest values of substitutions, either synonymous or non-synonymous, and the highest virus diversity, evaluated by genetic distance, were found in patients with sustained virological responses (SVR). Studies on genotype $1 \mathrm{~b}$ have reported that the number of mutations in a specific region of NS5A, ISDR, could predict an SVR [17-21]. Since other studies refute these results, a metaanalysis was performed with American, European and Japanese sequences [22-30] that allowed a positive correlation to be established between mutations in the ISDR region and SVR. The same study also revealed a geographic correlation; mutations in the Japanese sequences had a higher probability of leading to SVR than mutations in European sequences. The authors suggested that geographic variation may be related to host factors. This meta-analysis included sequences of genotype 1, but no South American sequences were considered. Since the European and Japanese strains yielded different results, other populations may also present a different pattern.

Although the SVR group showed higher mutation values in the region NS5A by either $b s$ or $w s$ analysis in our study, the $\mathrm{dN} / \mathrm{dS}$ ratio was higher in the group of non-responders (NR). Therefore, though SVR showed more mutations, NR strains had relatively more nonsynonymous substitutions. Amino acid mutations are most commonly deleterious because of the changes they cause in the protein phenotype. However, some of these substitutions are neutral when the mutation does not affect protein function, and are maintained by genetic drift. The higher rates of non-synonymous mutations detected in NR patients may indicate an advantage in evading both the immune system and the treatment, since they may be able to modify epitopes so that they are no longer recognized by the immune system.

For any given genome, the mutation rate determines the ability of a virus to maintain essential information while coping with environmental changes [16,31-39]. All values obtained for comparisons between $\mathrm{dN}$ and $\mathrm{dS}$ using the $\mathrm{dN} / \mathrm{dS}$ ratio were below 0.5 . These findings indicate that the NS5A protein is undergoing purifying selection, which maintains protein function and therefore virus activity.

The occurrence of stop codons in the same site has been described previously in the literature. In a similar study, performed on patients infected with HCV genotype 1, two stop codons were found in the same site of the CRS region in two different patients [40]. Also, studies with the Dengue Virus, another Flavivirus, have found the same stop codons in $23 \%$ of samples studied. These strains circulated in the population studied for 18 months. These studies suggest that defective genomes can circulate with the assistance of non-defective strains [41,42]. A recent study with Hepatitis C Virus demonstrated that as the virus circulates in the blood, defective genomes can be encapsidated as infectious particles by trans complementation (acting on a viral RNA other than the one from which it has been translated) of the structural proteins. NS5A protein was also shown to be the only non-structural protein that acts in trans in $\mathrm{HCV}$ as well as other Flavivirus, so it could be acting as a helper to defective genomes [43-45].

Of the two analytical approaches used in this study, within-sample (ws) analysis is relevant when the focus of the study is the patient profile, to study a population, in this case a response group; the statistical power is very low and no or few assumptions can be made. However, between-sample (bs) data represent the response group value better, since it is obtained using all 60 sequences from each group. This approach is more accurate when the aim is to identify a pattern from the response group. The $b s$ analyses normalize characteristics that are exclusive to individual patients, by using a pool of strains from the same response group. In most cases they yielded statistical significance. Thus, even though the population size of our study is relatively low (12 patients), statistical significance was obtained, supporting the data on the response group patterns discussed.

\section{Conclusion}

This is the first study on the quasispecies composition of the complete NS5A region of HCV genotype $3 \mathrm{a}$. Although we found differences among the response groups, other studies are necessary for a better understanding of the relationship between the variability of this region and the response to treatment with interferon and ribavirin, since most studies are performed with genotype 1 , and the genomic differences among these genotypes are significant.

\section{Methods}

\section{Population and samples}

Plasma samples were collected from $12 \mathrm{HCV}$ genotype 3-positive patients, seen at the Hemocenter of São José do Rio Preto, State of São Paulo, Brazil. All samples 
were collected before treatment, and a 6-months followup provided treatment response data. Four patients were sustained virological responders (SVR), i.e the virus was not detected after treatment or during the 6-months follow-up; four were non-responders (NR), since they showed no virological response; and four were end-oftreatment responders (ETR), i.e. a virological response was detected, but at the 6-months follow-up there was a rebound. All patients were infected with $\mathrm{HCV}$ genotype 3a. Treatment consisted of INF- $\alpha$ and ribavirin administration for 24 weeks. Patients with a history of alcoholism or infection with another agent that could cause liver damage were excluded. This study was approved by the ethics committee of the Base Hospital of São José do Rio Preto, and all participants signed an informed consent.

\section{Viral load}

The viral load was quantified by Cobas TaqMan HCV Test.

\section{Extraction of HCV RNA and amplification of the NS5A region}

Viral RNA was extracted from blood serum samples using a QIAamp Viral RNA Mini Kit (QIAgen), and cDNA was synthesized using a High-Capacity cDNA Archive Kit (Applied Biosystems) according to the manufacturer's instructions. The NS5A region was amplified using a set of primers specific for genotype 3, designed for this study. For the PCR reaction, two sets of forward and reverse primers were designed. The forward primers were H.NS5AP-F (5' GAGCGGTACAGTGGATGAAC 3' - nucleotide [nt] 6089 to 6108 in genotype 3 reference sequence NZL1 - GenBank D17763G) and H.NS5AP-F2 (5' GGTACAGTGGATGAACAGG 3' - nt 6093 to 6111 in NZL1). The reverse primers were H.NS5AP-R (5' CCTCCTTTAATGCAGTCTTG 3' - nt 7821 to 7840 in NZL1) and H.NS5AP-R2 (5' ACGACGTTGAATAGACTAGG 3' nt 7734 to 7753 in NZL1). Two sets of forward and reverse primers were also designed for the nested-PCR reaction. The forward primers were $H$. NS5AN-F (5' CGCATTGCTGAGTTCTCTAAC 3' from nt 6192 to 6212 in NZL1) and H.NS5AN-F2 (5' CTCTAACTGTCACAAGTCTGC 3' nt 6206 to 6226 in NZL1). The reverse primers were H.NS5AN-R (5' CAACAAGGAGTTGCTGAGTG 3' nt 7703 to 7722 in NZL1) and H.NS5AN-R2 (5' CAGCACTACATGGTGTTATC 3' nt 7659 to 7678 in NZL1). For the amplification reaction, $1 \mathrm{U}$ of a proofreading polymerase was used (Elongase ${ }^{\odot}$ Enzyme Mix; Invitrogen) along with $10 \mu \mathrm{l}$ of buffer $\mathrm{B}$ [300 mM Tris- $\mathrm{SO}_{4},\left(\mathrm{pH} 9.1\right.$ at $25^{\circ} \mathrm{C}$ ), $90 \mathrm{mM}\left(\mathrm{NH}_{4}\right)_{2} \mathrm{SO}_{4}$ and $\left.10 \mathrm{mM} \mathrm{MgSO}_{4}\right], 10 \mu \mathrm{l}$ of dNTP, $30 \mathrm{pmol}$ of sense and anti-sense primers, $10 \mu \mathrm{l}$ of cDNA for PCR reaction, and $5 \mu \mathrm{l}$ of PCR product for the
nested-PCR reaction, plus Milli-Q autoclaved water to a final volume of $50 \mu \mathrm{l}$. The amplified products were analyzed on a $1 \%$ agarose gel.

\section{Cloning and sequencing}

Cloning was performed using a TOPO XL Cloning TM Kit (Invitrogen). Fragments from 15 clones from each patient were purified using a PureLink Mini-prep Plasmid Purification Kit (Invitrogen). The entire NS5A region was sequenced using eight primers: the vector primers $M 13 F$ and $M 13 R$, and six inner primers, three sense and three anti-sense, designed for this study. The forward primers used in the sequencing reaction were: H.NS5AI-F1 (5' TGGCTGCGTATCATCTGGGA 3' - nt 6283 to 6302 in NZL1), H.NS5AI-F2 (5' ACCTCGATGTTGAGAGACCC 3' - nt 6871 to 6890 in NZL1) and H.NS5AI-F3 (5' TATCCTCCAGCCCTTCCTAT 3' nt 7198 to 7217 in NZL1). The reverse primers used in the sequencing reaction were: H.NS5AI-R1 (5' CACGGACACTTGAGCTCATC 3' - nt 6679 to 6698 in NZL1), H.NS5AI-R2 (5' TTCTTGAAACACTCTGCAGC $3^{\prime}$ - nt 7168 to 7187 in NZL1) and H.NS5AI-R3 (5' GTGGACCAAGAGTCGCAACT 3' - nt 7573 to 7592 in NZL1). The sequencing reaction was performed with Dyenamic ET Terminator (GE) and the products were sequenced in an ABI Prism 377 sequencer (Applied Biosystems). The reaction mixture consisted of $1 \mu \mathrm{l}$ of Milli-Q autoclaved water, $1 \mu \mathrm{l}$ of primer $(5 \mathrm{pmol} / \mu \mathrm{l})$, $2 \mu \mathrm{l}$ of sequencing reagent mix, plus $2 \mu \mathrm{l}$ of sample. Occasionally, when a good quality sequence could not be obtained, the sequencing reaction had to be doubled and a "hot start" had to be performed for $10 \mathrm{~min}$ at $95^{\circ}$ $\mathrm{C}$ for better results. Cycling was carried out according to the manufacturer's instructions.

\section{Sequence and phylogenetic analysis}

The sequences obtained were subjected to BioMol Electropherogram quality analysis http://adenina.biomol. unb.br/phph/[46], a phred phrap [47,48] analysis site, for quality check and contig construction. The contigs obtained for each clone were aligned, along with the reference sequence NZL1 for genotype 3 (GenBank accession number D17763), using Clustal X 1.81 software [49]. All sequences were edited on Bio Edit 7.0.5.3 [50] to remove the vector fragments, leaving only the complete sequence of the NS5A region.

Quasispecies analysis was carried out using LOCSPEQ 1.0 software [51], specially designed for our group for this kind of analysis.

The number of mutations and the genetic distances were calculated using MEGA 4.0 software [52]. The rates of synonymous substitution per synonymous site (dS) and non-synonymous substitution per non-synonymous site $(\mathrm{dN})$, as well as the $\mathrm{dN} / \mathrm{dS}$ ratio, were 
obtained at SNAP - Synonymous Non-synonymous Analysis Program -http://www.hiv.lanl.gov[53,54].

Phylogenetic analysis was performed using PAUP*version 4 software [55]. A neighbor-joining phylogenetic tree was constructed with Tamura-Nei's substitution model including invariant sites (I) and Gamma distribution shape $(\mathrm{G})$ parameter $(\mathrm{TRN}+\mathrm{I}+\mathrm{G})$, determined by hierarchical likelihood ratio test score criteria using Modeltest 3.06 [56]. One thousand replicates were used to test the reliability of the tree topology, and bootstrap values $>70$ were considered significant [57].

\section{Statistical analysis}

Statistical analysis was performed by ANOVA. Comparisons between groups were made using Tukey's method for multiple comparisons. Values of $\mathrm{P}<0.05$ were considered significant. Standard error of the mean (SEM) values were calculated in Minitab 15.

\section{Types of analysis}

In this work, we chose to analyze the results obtained by two different approaches:

\section{Within-sample analysis (ws)}

This consisted of calculating the means of genetic distances, $\mathrm{dS}, \mathrm{dN}$ and $\mathrm{dN} / \mathrm{dS}$ ratios among the clones of one patient, and then calculating the mean of the four values obtained for each patient in the response group to obtain the group value.

\section{Between-sample analysis (bs)}

This consisted of calculating the means of genetic distances, $\mathrm{dS}, \mathrm{dN}$ and $\mathrm{dN} / \mathrm{dS}$ ratios among all the clones of the response group to obtain the group values.

\section{Nucleotide sequence accession numbers}

The nucleotide sequence data reported here have been submitted to the GenBank nucleotide sequence database with accession numbers from EU826174 to EU826352.

\section{Acknowledgements}

This work was financially supported by FAPESP and CAPES.

\begin{abstract}
Author details
'UNESP, São Paulo State University, IBILCE, Institute of Bioscience, Language \& Literature and Exact Science, Department of Biology, Rua Cristóvão Colombo, 2265 , Bairro Jardim Nazareth, CEP 15054-010, São José do Rio Preto, São Paulo, Brazil. '2USP, São Paulo University, Rua do Matão, trav 14, n 321, Cidade Universitária, CEP 05508-900, São Paulo, São Paulo, Brazil. ${ }^{3}$ USP, São Paulo University, Faculty of Medicine, Department of Gastroenterology, Laboratory of Hepatology and Gastroenterology from Institute of Tropical Medicine, Av Dr Arnaldo, 455, Cerqueira César, CEP: 01246903, São Paulo, SP Brazil. ${ }^{4}$ Albert Einstein Israeli Hospital, Department of Clinical Pathology, Av Albert Einstein, 627/701, CEP 05652-000São Paulo, SP, Brazil. ${ }^{5}$ Butantan Institute, Viral Immunology Laboratory, Av Vital Brasil n² 1500, CEP 05503900, Butantã, São Paulo, SP, Brazil.
\end{abstract}

\section{Authors' contributions}

CB, ACGJ, IMVGCM, PR: contributed to the study design, carried out the molecular biology experiments, sequence alignment, phylogenetic analysis and manuscript planning; LHTY: carried out the molecular biology experiments; ATLQ: performed statistical analysis; CMAC: contributed with significant evolutionary knowledge on data analysis; JRRP: contributed to the study design. All authors read and approved the final manuscript.

\section{Competing interests}

The authors declare that they have no competing interests.

Received: 9 April 2009

Accepted: 23 February 2010 Published: 23 February 2010

\section{References}

1. Bowen DG, Walker CM: Adaptive immune responses in acute and chronic hepatitis C virus infection. Nature 2005, 436(7053):946-952.

2. Alter MJ: Epidemiology of hepatitis C virus infection. World J Gastroenterol 2007, 13(17):2436-2441.

3. Choo QL, Kuo G, Weiner AJ, Overby LR, Bradley DW, Houghton M: Isolation of a cDNA clone derived from a blood-borne non- $A$, non- $B$ viral hepatitis genome. Science 1989, 244(4902):359-362.

4. Martell M, Esteban JI, Quer J, Genesca J, Weiner A, Esteban R, Guardia J, Gomez J: Hepatitis $C$ virus ( $\mathrm{HCV}$ ) circulates as a population of different but closely related genomes: quasispecies nature of HCV genome distribution. J Virol 1992, 66(5):3225-3229.

5. Silva LK, Parana R, Souza SP, Berby F, Kay A, Trepo C, Santana N, Cotrim H, Lyra LG, Reis MG: Hepatitis $C$ virus genotypes in a northeastern area of Brazil. Am J Trop Med Hyg 2000, 62(2):257-260.

6. Campiotto S, Pinho JR, Carrilho FJ, Da Silva LC, Souto FJ, Spinelli V, Pereira LM, Coelho HS, Silva AO, Fonseca JC, et al: Geographic distribution of hepatitis C virus genotypes in Brazil. Braz J Med Biol Res 2005, 38(1):41-49.

7. Bukh J, Miller $\mathrm{RH}$, Purcell $\mathrm{RH}$ : Genetic heterogeneity of hepatitis $\mathrm{C}$ virus: quasispecies and genotypes. Semin Liver Dis 1995, 15(1):41-63.

8. Domingo E, Escarmis C, Sevilla N, Moya A, Elena SF, Quer J, Novella IS, Holland JJ: Basic concepts in RNA virus evolution. Faseb J 1996, 10(8):859-864.

9. Forns X, Bukh J: The molecular biology of hepatitis C virus. Genotypes and quasispecies. Clin Liver Dis 1999, 3(4):693-716.

10. Forns $X$, Purcell RH, Bukh J: Quasispecies in viral persistence and pathogenesis of hepatitis C virus. Trends Microbiol 1999, 7(10):402-410.

11. Farci P, Strazzera R, Alter HJ, Farci S, Degioannis D, Coiana A, Peddis G, Usai F, Serra G, Chessa L, et al: Early changes in hepatitis $C$ viral quasispecies during interferon therapy predict the therapeutic outcome. Proc Natl Acad Sci USA 2002, 99(5):3081-3086.

12. Le Guillou-Guillemette H, Vallet S, Gaudy-Graffin C, Payan C, Pivert A, Goudeau A, Lunel-Fabiani F: Genetic diversity of the hepatitis C virus: impact and issues in the antiviral therapy. World J Gastroenterol 2007, 13(17):2416-2426.

13. Gale M Jr, Foy EM: Evasion of intracellular host defence by hepatitis $C$ virus. Nature 2005, 436(7053):939-945

14. Eigen $M$, Biebricher C: Sequence space and quasispecies distribution. Boca Raton, FL: CRC Press 1988, 3.

15. Eigen M: Viral quasispecies. Sci Am 1993, 269(1):42-49

16. Coffin JM: HIV population dynamics in vivo: implications for genetic variation, pathogenesis, and therapy. Science 1995, 267(5197):483-489.

17. Enomoto N, Sakuma I, Asahina $Y$, Kurosaki M, Murakami T, Yamamoto C Ogura Y, Izumi N, Marumo F, Sato C: Mutations in the nonstructural protein $5 \mathrm{~A}$ gene and response to interferon in patients with chronic hepatitis C virus 1b infection. N Engl J Med 1996, 334(2):77-81.

18. Chayama K, Tsubota A, Kobayashi M, Okamoto K, Hashimoto M, Miyano Y, Koike H, Kobayashi M, Koida I, Arase Y, et al: Pretreatment virus load and multiple amino acid substitutions in the interferon sensitivitydetermining region predict the outcome of interferon treatment in patients with chronic genotype $1 \mathrm{~b}$ hepatitis $\mathrm{C}$ virus infection. Hepatology 1997, 25(3):745-749.

19. Arase Y, Ikeda K, Chayama K, Murashima N, Tsubota A, Suzuki Y, Saitoh S, Kobayashi M, Kobayashi M, Kobayashi M, et al: Efficacy and changes of the nonstructural 5A GENE by prolonged interferon therapy for patients with hepatitis $C$ virus genotype $1 \mathrm{~b}$ and a high level of serum HCV-RNA. Intern Med 1999, 38(6):461-466.

20. Kurosaki M, Enomoto N, Murakami T, Sakuma I, Asahina Y, Yamamoto C, Ikeda T, Tozuka S, Izumi N, Marumo F, et al: Analysis of genotypes and 
amino acid residues 2209 to 2248 of the NS5A region of hepatitis C virus in relation to the response to interferon-beta therapy. Hepatology 1997, 25(3):750-753

21. Nakano I, Fukuda Y, Katano Y, Nakano S, Kumada T, Hayakawa T: Why is the interferon sensitivity-determining region (ISDR) system useful in Japan?. J Hepatol 1999, 30(6):1014-1022.

22. Berg T, Mas Marques A, Hohne M, Wiedenmann B, Hopf U, Schreier E: Mutations in the E2-PePHD and NS5A region of hepatitis C virus type 1 and the dynamics of hepatitis $\mathrm{C}$ viremia decline during interferon alfa treatment. Hepatology 2000, 32(6):1386-1395.

23. Duverlie G, Khorsi H, Castelain S, Jaillon O, Izopet J, Lunel F, Eb F, Penin F, Wychowski C: Sequence analysis of the NS5A protein of European hepatitis $C$ virus $1 \mathrm{~b}$ isolates and relation to interferon sensitivity. $J$ Gen Virol 1998, 79(Pt 6):1373-1381.

24. Sarrazin C, Berg T, Lee JH, Ruster B, Kronenberger B, Roth WK, Zeuzem S: Mutations in the protein kinase-binding domain of the NS5A protein in patients infected with hepatitis $C$ virus type $1 \mathrm{a}$ are associated with treatment response. J Infect Dis 2000, 181(2):432-441.

25. Squadrito G, Orlando ME, Cacciola I, Rumi MG, Artini M, Picciotto A, Loiacono O, Siciliano R, Levrero M, Raimondo G: Long-term response to interferon alpha is unrelated to "interferon sensitivity determining region" variability in patients with chronic hepatitis $\mathrm{C}$ virus- $1 \mathrm{~b}$ infection. J Hepatol 1999, 30(6):1023-1027.

26. Zeuzem S, Lee JH, Roth WK: Mutations in the nonstructural $5 \mathrm{~A}$ gene of European hepatitis $C$ virus isolates and response to interferon alfa. Hepatology 1997, 25(3):740-744.

27. Chung RT, Monto A, Dienstag JL, Kaplan LM: Mutations in the NS5A region do not predict interferon-responsiveness in american patients infected with genotype 1b hepatitis C virus. J Med Virol 1999, 58(4):353-358.

28. Nousbaum J, Polyak SJ, Ray SC, Sullivan DG, Larson AM, Carithers RL Jr, Gretch DR: Prospective characterization of full-length hepatitis $C$ virus NS5A quasispecies during induction and combination antiviral therapy. $J$ Virol 2000, 74(19):9028-9038.

29. Murphy MD, Rosen HR, Marousek Gl, Chou S: Analysis of sequence configurations of the ISDR, PKR-binding domain, and V3 region as predictors of response to induction interferon-alpha and ribavirin therapy in chronic hepatitis C infection. Dig Dis Sci 2002, 47(6):1195-1205.

30. Pascu M, Martus P, Hohne M, Wiedenmann B, Hopf U, Schreier E, Berg T: Sustained virological response in hepatitis $C$ virus type $1 \mathrm{~b}$ infected patients is predicted by the number of mutations within the NS5A-ISDR: a meta-analysis focused on geographical differences. Gut 2004, 53(9):1345-1351.

31. Domingo E, Holland Jj: Mutation rates and rapid evolution of RNA viruses. The Evolutionary Biology of Viruses Edited by Raven. New York 1994, 161-184.

32. Domingo E, Holland JJ, Ahlquist P: RNA Genetics. Boca Raton, FL: CRC Press 1988.

33. Domingo E, Holland JJ, Biebricher C, Eigen M: Quasispecies: the concept and the word. Molecular Evolution of the Viruses Cambridge: Cambridge Univ. PressGibbs A, Calisher C, García-Arenal F 1995, 171-180.

34. Domingo E, Martinez-Salas E, Sobrino F, de la Torre JC, Portela A, Ortin J, Lopez-Galindez C, Perez-Brena P, Villanueva N, Najera R, et al: The quasispecies (extremely heterogeneous) nature of viral RNA genome populations: biological relevance-a review. Gene 1985, 40(1):1-8.

35. Gebauer F, de la Torre JC, Gomes I, Mateu MG, Barahona H, Tiraboschi B, Bergmann I, de Mello PA, Domingo E: Rapid selection of genetic and antigenic variants of foot-and-mouth disease virus during persistence in cattle. J Virol 1988, 62(6):2041-2049.

36. Holland Jj: Continuum of change in RNA virus genomes. Concepts in Viral Pathogenesis New York: Springer-VerlagNotkins AL, Oldstone MBA 1984, 137-143.

37. Holland J, de la Torre JC, Steinhauer DA: RNA virus populations as quasispecies. Curr Top Microbiol Immunol 1992, , 176: 1-20.

38. Temin HM: Is HIV unique or merely different?. J Acquir Immune Defic Syndr 1989, 2(1):1-9.

39. Wei $X$, Ghosh SK, Taylor ME, Johnson VA, Emini EA, Deutsch P, Lifson JD, Bonhoeffer S, Nowak MA, Hahn BH, et al: Viral dynamics in human immunodeficiency virus type 1 infection. Nature 1995, 373(6510):117-122.

40. Jardim AC, Yamasaki LH, de Queiroz AT, Bittar C, Pinho JR, Carareto CM, Rahal P, Mello IM: Quasispecies of hepatitis $C$ virus genotype 1 and treatment outcome with Peginterferon and Ribavirin. Infect Genet Evol 2009, 9(4):689-698.

41. Craig S, Thu HM, Lowry K, Wang XF, Holmes EC, Aaskov J: Diverse dengue type 2 virus populations contain recombinant and both parental viruses in a single mosquito host. J Virol 2003, 77(7):4463-4467.

42. Aaskov J, Buzacott K, Thu HM, Lowry K, Holmes EC: Long-term transmission of defective RNA viruses in humans and Aedes mosquitoes. Science 2006, 311(5758):236-238.

43. Sugiyama K, Suzuki K, Nakazawa T, Funami K, Hishiki T, Ogawa K, Saito S, Shimotohno KW, Suzuki T, Shimizu Y, et al: Genetic analysis of hepatitis C virus with defective genome and its infectivity in vitro. J Virol 2009, 83(13):6922-6928.

44. Tong $X$, Malcolm BA: Trans-complementation of HCV replication by nonstructural protein 5A. Virus Res 2006, 115(2):122-130.

45. Appel $N$, Herian $U$, Bartenschlager R: Efficient rescue of hepatitis $C$ virus RNA replication by trans-complementation with nonstructural protein 5A. J Virol 2005, 79(2):896-909.

46. BioMol - Electropherogram quality analysis. http://www.biomol.unb.br/ $\mathrm{phph} /$.

47. Ewing B, Green P: Base-calling of automated sequencer traces using phred. II. Error probabilities. Genome Res 1998, 8(3):186-194.

48. Ewing B, Hillier L, Wendl MC, Green P: Base-calling of automated sequencer traces using phred. I. Accuracy assessment. Genome Res 1998, 8(3):175-185.

49. Thompson JD, Gibson TJ, Plewniak F, Jeanmougin F, Higgins DG: The CLUSTAL_X windows interface: flexible strategies for multiple sequence alignment aided by quality analysis tools. Nucleic Acids Res 1997, 25(24):4876-4882.

50. Hall TA: BioEdit: a user-friendly biological sequence alignment editor and analysis program for Windows 95/98/NT. Nucleic Acids Symposium Series 1999, 41:95-98.

51. Marucci EA, Zafalon GF, Jardim AC, Yamasaki LH, Bittar C, Rahal P, Machado JM: Routine libraries for pattern recognition in quasispecies. Genet Mol Res 2008, 7(3):970-981.

52. Tamura K, Dudley J, Nei M, Kumar S: MEGA4: Molecular Evolutionary Genetics Analysis (MEGA) Software Version 4.0. Mol Biol Evol 2007, 24(8):1596-1599

53. Korber B: HIV Signature and Sequence Variation Analysis. Computational Analysis of HIV Molecular Sequences. Dordrecht, Netherlands: Kluwer Academic Publishers 2000.

54. HCV sequence database. http://www.hiv.lanl.gov.

55. Swofford DL: PAUP* Phylogenetic Analysis Using Parsimony (*and Others Methods). Sunderland, Massachusetts 2002.

56. Posada D, Crandall KA: MODELTEST: testing the model of DNA substitution. Bioinformatics 1998, 14(9):817-818.

57. McCormack GP, Clewley JP: The application of molecular phylogenetics to the analysis of viral genome diversity and evolution. Rev Med Virol 2002, 12(4):221-238.

\section{Pre-publication history}

The pre-publication history for this paper can be accessed here:http://www biomedcentral.com/1471-2334/10/36/prepub

doi:10.1186/1471-2334-10-36

Cite this article as: Bittar et al: Genetic diversity of NS5A protein from hepatitis $C$ virus genotype $3 a$ and its relationship to therapy response. BMC Infectious Diseases 2010 10:36. 